\title{
A não-propriedade: Um tema franciscano de ontem e hoje
}

\author{
Jerónimo Bórmida
}

\section{Um tema do século XIV}

Fazer teologia latinoamericana não significa necessariamente estudar, investigar, escrever sobre temas latinomericanos. É intentar um discurso teológico com perspectiva latinoamericana, o qual significa, de algum modo, "tomar partido hermenêtico". Quando o teólogo formula tal opção metodológica pressupõe, a priori, certo grau de validade na hermenêutica dos dados de fé que têm ou tiveram os condenados, os frustrados, os malsucedidos, os que terminaram como perdedores nos confrontos com o poder ao longo da história ${ }^{1}$.

Ao abordar o estudo do conflito entre o papado e a Ordem Franciscana na primeira metade do século XIV, parte de uma hipótese: a leitura dos acontecimentos tal como os temos recebido está ligada e é dependente da hermenêutica do vencedor. Na minha investigação começo por suspeitar da dita leitura. O ter-se "apropriado dos fatos" não implica necessariamente em ser dono da verdade, nem possuir a chave de leitura correta. Os poderosos não são necessariamente os artífices do projeto eterno de Deus que se vai realizando no tempo.

Os franciscanos, da primeira metade do século XIV, contrapõem à Igreja oficial seu Cristo, sem propriedade e sua comunidade apostólica sem propriedades. Não estão fazendo uma formulação cristológica, estão lançan-

\footnotetext{
${ }^{1}$ Refiro-me ao meu livro No-Propriedad, una propuesta de los franciscanso del Siglo XIV, Montevideo, 1996; tradução portuguesa, de Isidoro Mazzarolo, Porto Alegre, ESTEF, 1997.
} 
do uma proposta englobante, estejam ou não conscientes da gravidade e do alcance de seu debate que tinham iniciado. Quem aceitar a tese franciscana da "altíssima" pobreza, necessariamente se verá obrigado a reformular sua imagem de Deus, de Igreja e de sociedade. Terá que eliminar de seu vocabulário palavras tais como "amo", "dono", "patrão", para introduzir outras como "irmão", "igual", "livre"...

Essa é a raiz das tensões provocadas pela postura franciscana. Os franciscanos não se dedicarão a eliminar toda a forma de propriedade na terra? Não é essa, no fundo, a sua perigosa utopia?

Que Jesus Cristo tivesse ou não propriedades, tanto como pessoa, como comunidade apostólica, mais ainda, que tivesse o direito de possuir e alienar as coisas que possuíam, pode parecer uma questão menor, ao estilo das questões disputadas nas universidades. Porém, da postura cristológica assumida se deduzia outro tipo de direito à propriedade privada na sociedade e na Igreja. Sustentar que a Igreja, discípula e esposa de Cristo, tivesse o direito a possuir era "herético", contrário à verdadeira fé, à práxis evangélica ortodoxa.

No artigo que trata sobre a propriedade, Santo Tomás traz a colação da "autoridade" de Santo Agostinho, que condena a quem pretende converter o mundo em um mosteiro. Cristo assumiu em tudo a condição humana e por isso teve a propriedade que tiveram os seres humanos. Como diz o Doutor que se é justa e meritória a opção dos que renunciam à propriedade, não é igualmente justificável a pretensão de quem impõe tal forma de vida a toda a cristiandade. No fundo, Santo Tomás supõe um tipo de vida religiosa que não é a utopia-modelo que constrói a sociedade, mas ao contrário, é o projeto religioso aparece modelado por uma sociedade e viável só para os escolhi$\operatorname{dos}^{2}$.

Se costumava distinguir quatro modos, segundo sendo os quais, Cristo havia mantido propriedade do dinheiro. O primeiro era na "condescendência", para consolo dos imperfeitos e débeis; o segundo o de "admoestação", a fim de admoestar os hereges, os quais, a exemplo dos maniqueus, condenavam como pecado a possessão de bens temporais por parte da Igreja; o terceiro é o "ameaçador" para ameaçar os avarentos com o mesmo destino de Judas; o quarto, a fim de "servir de informação ao estado de perfeição".

\footnotetext{
2 "Santo Agostinho diz em sua obra De haeresis: Há os que arrogantemente se denominam 'apostólicos'. Essas pessoas não admitem em sua comunhão aqueles que usam de mulheres e possuem propriedades privadas, tal como foi costume na Igreja apostólica e o é hoje em dia entre muitos clérigos e monges'. Esses tais são hereges, dado que se afastam da Igreja, sem conceder nenhuma esperança aos que usam os bens dos quais eles se privam”, São Tomás, IIa IIae q. 66,a2.
} 
Nos estados de perfeição distinguiam-se três níveis: no primeiro, Cristo foi modelo da perfeição para os cenobitas, para que estes de nada se apropriassem, mas tivessem todas as coisas em comum, segundo a forma transmitida pelos apóstolos aos primeiros crentes, como se lê nos At 4,32-36... O segundo, Cristo foi modelo de perfeição para os prelados da Igreja, que são os dispensadores dos bens da Igreja para o sustento dos pobres. $\mathrm{O}$ terceiro, simplesmente usando do dinheiro, foi modelo de perfeição dos apóstolos, que careciam do dinheiro, porem eram acompanhados de mulheres que os assistiam com seus bens ${ }^{3}$.

Para o movimento franciscano, o tema da propriedade era resposta a uma pergunta muito mais simples e mais profunda: É possível outra sociedade e outra economia?

A resposta do movimento foi positiva: é possível outra economia e, passa necessariamente por revisar a fundo o tema da propriedade, da apropriação humana dos bens que são de Deus e que têm sido dadas para o uso comum.

\section{Propriedade, não pobreza}

A controvérsia que os franciscanos e o papado mantiveram na primeira metade do século XIV não esteve centrada na "pobreza de Cristo". O ponto focal do debate é o da relação de Cristo com a propriedade e, conseqüentemente, com o tema correlativo do poder.

Entre São Francisco e o franciscanismo que entra na primeira metade do século XIV existe uma "continuidade dinâmica" difícil de manejar. Por uma parte parece inegável que a negação de todo tipo de propriedade privada funde suas raízes na experiência e doutrina de Francisco e de sua primeira comunidade. E por outra, a distância de mais de um século, a proposta sobre a propriedade e o poder é radicalmente inovadora ${ }^{4}$.

\section{Propriedade e uso pobre}

No século XIV a Ordem Franciscana se encontra profundamente divida entre "Espirituais" e "Comunidade". Na relação com o tema da propriedade, o pensamento é relativamente unânime, a disputa interna se concentra

\footnotetext{
${ }^{3}$ TABARRONI, A., Paupertas Christi et Apostolorum. L'ideale francescano in discussione (1322-1324), Roma, Instituto Stórico per il Médio Evo, 1990, 37-38.

${ }^{4} \mathrm{Na}$ realidade não me interessa tanto o pensamento de São Francisco, senão a evolução do movimento franciscano.
} 
no tema do uso pobre. O princípio da não-propriedade era inegociável tanto para a comunidade como para os espirituais.

A discussão entre Ordem Franciscana e Papado, a fim de determinar se Cristo teve ou não propriedades, pode parecer um problema alheio aos problemas reais, pelos quais se vive e se morre realmente: não parece ser um tema que interesse hoje à transformação da realidade. Porém a disputa no interior da Ordem não se centraliza em torno do tema da Propriedade, que parece, ao menos relativamente, pacífico. O ponto de discussão parece ser o do uso pobre ao qual estariam ou não obrigados pela profissão da Regra. A "Exivi de paradiso" afirma que os irmãos, pela profissão da sua regra estão obrigados a um uso das coisas limitado, exíguo e pobre. Diz o Papa Clemente:

"Tem surgido uma questão bastante enfastiante entre os irmãos, a saber - se pela profissão de sua regra estão obrigados a um uso limitado, exíguo e pobre".

"Alguns acreditam e afirmam que assim como na relação com a propriedade das coisas estão obrigados, em razão do voto, a uma renúncia radical, do mesmo modo a limitação do uso, também terá que ser máxima e que não haja argumentos em contrário.

"Outros, ao contrário, sustentam que não estão obrigados por sua profissão a nenhum tipo de uso pobre, fora do expressamente mencionado na Regra. Por mais que estejam, sim, convenientemente obrigados ao uso moderado que supõe a temperança, com igual ou maior grau que os demais cristãos".

"Os irmãos Menores estão especialmente obrigados, em razão de sua profissão, ao uso pobre ou limitado que está expresso em sua mesma Regra, e com as modalidades que nela constam".

"É presunçoso o afirmar, como alguns pretendem, que é herético sustentar que o uso pobre está ou não contido no voto da evangélica pobreza".

Todo o problema se resume nessas perguntas: Qual o sentido último da ralação do homem com as coisas que propunham os franciscanos? Queriam apenas para si próprios ou fazem de sua proposta um modelo para a Igreja e para o mundo?

Tanto o tema da vontade apropriativa do homem, como o do uso e abuso dos bens desse planeta é que estão no centro das pistas de saída para o

\footnotetext{
${ }^{5}$ CLEMENTE V, 1311-1312, Bullarium Franciscanum V, 85.
} 
homem do século XXI. O franciscanismo, historicamente, teve interesse pelos temas sociais em geral e pelos econômicos, em particular e, lamentavelmente nas bibliotecas especializadas na Idade Média se pode estudar sem problemas a história das idéias, porém, dificilmente se encontra material sobre a evolução da economia. É surpreendente constar que os grandes místicos espirituais de 1300 dedicaram muito tempo e esforço aos temas econômicos ${ }^{6}$.

\section{Centralidade teológica da temática}

O tema da pobreza ocupou um dos lugares de preferência na vida e na reflexão dos crentes através de toda a história da Igreja ${ }^{7}$. A vida de Cristo pobre, no sermão da montanha com suas bem-aventuranças, a disposição em comum dos bens da Comunidade Primitiva, a vida dos padres do deserto, o desenvolvimento do monacato, tanto no Oriente quanto no Ocidente, vão se delineando como marcos na vida de comunidade dos fiéis. Em qualquer época nos encontramos com grupos de cristãos que propondo-se seguir a Jesus no modo mais próximo possível, assumem uma dimensão de pobreza mais ou menos radical ${ }^{8}$, que sempre implica na renúncia da propriedade pessoal, admitindo habitualmente a posse comunitária dos bens.

A temática da pobreza adquire uma máxima a partir da alta Idade Média. Assistimos a um florescimento de vida cristã de extraordinária vitalidade que está marcado pela pobreza, entendida mais como volta a Cristo pobre

\footnotetext{
${ }^{6}$ KIRSCHNER, Lo Prete, "I trattati di Pietro Giovanni Olivi sui contrati di vendita, di usura e di restitucione: "economia dei minori francescani o opere minori?" Bologna, 1987, in: CAPITANI, O., Una etica economica medievale, Colección de artículos; SPICCIANI, A., "Sant'Antonio, San Bernardino e Pier di Giovanni Olivi del pensiero econômico medievale", Bologna, 1987, 93-120, in: CAPITANI, O., Una economia politica nel Medioevo, Bologna, 1987.

${ }^{7}$ Pode-se ler nos livros de FARINA, M., Chiesa di poveri e chiesa dei poveri, La fondazione bíblica di um tema conciliare, Roma, 1986 e Chiesa di poveri e chiesa dei poveri, La memoria della chiesa, Roma, 1988. O primeiro contém abundantíssima bibliografia geral sobre o tema da pobreza.

8 "Se existe uma comunidade religiosa que se presta mal a ser colocada no interior das estruturas da Ordem medieval, é sem dúvida, a Franciscana. A Regra Franciscana é um documento literário e doutrinal portador de um discurso substancialmente inovador e antecipador das exigências e ideais que emergiriam à superfície decididamente nos séculos seguintes. A controvérsia sobre a pobreza põe impiedosamente ao nu a crise do mundo medieval, e é protagonista e promotora de novos caminhos de busca filosófica e jurídica. Contudo, essa controvérsia impregna toda a Idade Média mais madura, encontra nas escolas franciscanas seu momento, historicamente, válido e vital." GROSSI, P., "Usus facti, La nozione de proprietà nella inaugurazione dell'età nuova", in: CAPITANI, O., Una economia politica nel Medioevo, Bologna, 1987, 2.
} 
reencontrado nos evangelhos, que como um retorno à Igreja primitiva, tal como tinha sido nos movimentos monásticos dos séculos anteriores. $\mathrm{O}$ tema alcança seu clímax na Baixa Idade Média, com a questão da posse efetiva das propriedades por parte de Cristo e dos apóstolos, e do mesmo direito de possuir que eles tinham?

\section{Proposta revolucionária}

A partir do século XI a Igreja é sujeito de uma verdadeira "revolução religiosa". As classes dirigentes não tiveram nem a lucidez suficiente, nem a capacidade política suficiente para entender o vasto evangelismo pauperístico, sobretudo popular e leigo, enquanto força privilegiada de verdadeira mudança, tanto religiosa, como social, cultural e política.

Quando alguém se detém em ler os processos episcopais contra os "hereges", tem a impressão de não encontrar um princípio de consciência crítica da parte dos prelados. Estes não parecem dar-se conta que em suas mãos se encontra o futuro da Igreja. Não têm lucidez para perceber que estão tomando verdadeiras decisões religiosas, atos de grande importância e de capital importância para o destino da cristandade. A Igreja hierárquica não fez nada para evitar, muito pelo contrário, que o movimento laical pauperístico, "apostólico" degenerasse naquilo que o tempo chamava de "heresia".

É considerado herege aquele que de algum modo se integra em um movimento contestador radical, incapaz de integrar-se na evolução normal da sociedade. Não tanto porque opõe carisma à estrutura, mas por que apresenta um projeto institucional alternativo.

\section{A propriedade e a utopia de um mundo perfeito}

O movimento pauperístico nasce no século XII com a intenção de viver a vida cristã renovada no seguimento das leis de Cristo, tal como estão no texto dos evangelhos, que começam a se popularizar e levar um estilo de vida parecido ao dos apóstolos. Esse tipo de vida implicava em três níveis: Em primeiro lugar a opção por ser pobres, renunciando voluntariamente a

\footnotetext{
9 "Nos sentimos obrigados a pontualizar a perfeita indissolubilidade do discurso franciscano sobre a pobreza. Entre os "vai e vem" doutrinais que a história permanentemente propõe é muito raro encontrar tanta autonomia na gênesis e no desenvolvimento, tanta simplicidade de linhas, tanta demarcação de confins, como neste pensamento original franciscano projetado para o futuro, "escandalosamente" contestador das soluções oficialmente aceita-se de algum modo, desenraizado das matrizes circulantes na cultura medieval. Para quem quer estudar, como estamos fazendo, a noção de propriedade na crise da interpretação medieval, não encontrará nenhum filão literário tão fecundo como o presente", GROSSI, 1.
} 
todas as possessões desta terra; em segundo lugar a pregação itinerante do evangelho de acordo com o estilo apostólico; em terceiro lugar e aqui começam os verdadeiros problemas da "heresia", a denúncia da Igreja Hierárquica pretendendo que o clero vivesse de modo verdadeiramente cristão, evangélico e apostólico. Do contrário, teria que desmascará-los tanto como indignos, quanto como ilegítimos sucessores dos apóstolos.

Em primeiro lugar, a renúncia radical a toda a forma de propriedade ${ }^{10}$, no sentido mais óbvio do termo, supõe o desfazer-se de toda a propriedade sobre as coisas materiais, por mais que inclua ou suponha a dimensão espiritual. $\mathrm{O}$ "dominium" consiste na vontade dominativa do homem sobre o mundo e sobre si mesmo. O franciscano não apenas renuncia à sua soberania sobre as coisas do mundo, mas também se aliena "propter Deum" de seu "proprium", de sua individualidade, alienação que se converte em senhorio de si e, contemporaneamente, de sujeição a Deus ${ }^{11}$.

Na polêmica do século XIV todas as forças e setores se unem para defender algo que consideravam determinante da identidade franciscana: o estado de perfeição escatológico que Cristo antecipou implica na renúncia pura e simples a toda a forma de apropriação, que inclui a renúncia à propriedade e todo o domínio como tal, tanto a nível pessoal como comunitário.

Tanto Tomás de Aquino, como os Mestres Franciscanos do século XIV, na mais pura tradição evangélica e patrística, defendem a origem histórico-humana das estruturas sociais do poder e da propriedade. Na intenção de Deus, no ordenamento do mundo desejado por Deus, cujo símbolo é o paraíso ou a humanidade no "estado de inocência", as coisas são comuns e indivisas e o homem é totalmente livre. O projeto primitivo de Deus exclui propriedade e cercas e na terra-reino de Deus não há lugar para a divisão de classes entre senhores e vassalos.

No entanto, para a corrente de pensamento que representa João XXII ${ }^{12}$ e que condena a opinião franciscana, a propriedade e o poder, ou provém de Deus e estão na vigência desde que o homem apareceu sobre a terra, ou então, aparecem como evolução lógica da perfeição do homem. Estamos diante

\footnotetext{
10 "O dominium, tal como o entendiam os religiosos que faziam o voto de renunciar a ele, está essencialmente constituído por três potestades: a de usar algo de modo completamente independente da vontade de alguém; a de conservar e acumular e, por fim, a de defender e reivindicar em juízo", TABARRONI, A., 93.

${ }^{11}$ GROSSI, P., Idem, p. 56-57.

12 "João XXII repreendeu sem razão certo indivíduo que apelou contra sua autoridade afirmando que o direito de propriedade ou de domínio foi introduzido pelo direito civil e humano, ao que o papa argüiu que a Sagrada Escritura afirma evidentemente o contrário", OCKHAM, G., Brevilóquio sobre o principado tirânico, Petrópolis, 1988, p. 122.
} 
de cosmovisões humanas e cristãs divergentes que se fecham os punhos pelo poder acabam em enfrentamentos violentos.

Quando se descreve o "paraiso", de fato, se está descrevendo a utopia, o melhor dos mundos sonhados. Na "origem" o homem exerceu um perfeito senhorio sobre as coisas, porém, a medida da capacidade divina que o homem tem de comportar-se como "senhor", radica na ausência de apropriação ou da vontade dominadora ${ }^{13}$.

$\mathrm{Na}$ verdade, o pecado para os franciscanos, não foi a causa da propriedade e do poder, mas só sua ocasião, de fato, o pecado condiciona definitivamente a origem histórica do sistema atual de propriedade e de governo.

Em primeiro lugar deve-se deixar claro que não são instituições divinas, mas históricas, que têm sua origem e causa humana. Em segundo lugar, é mister afirmar que o significado social é sua única legitimação aceitável, tanto desde o ponto de vista humano quanto do da fé.

Em segundo lugar, é mister afirmar que o significado social é sua única legitimação aceitável, tanto desde o ponto de vista humano quanto o da fé. Essas afirmações serão de capital importância no desenvolvimento do pensamento político-econômico posterior: se a autoridade não vem de Deus, as propriedades dos pagãos, dos infiéis, dos católicos que não estão em estado de graça, são tão legítimas ${ }^{14}$, como legítimos são os acordos sociais précristãos que estabeleceram o sistema jurídico de apropriação. Pense-se nas conseqüências para a doutrina papal que se outorgou, posteriormente, o direito de conceder terras de infiéis a reis católicos da Espanha e Portugal.

\footnotetext{
13 "Ockham supõe três etapas históricas no sistema de propriedade. Antes do pecado, no estado de inocência, o homem exercia um tipo de senhorio que excluía todo o tipo de discórdias, desavenças e a união reinavam em todo o lugar. Desse tipo de domínio não temos experiência e no presente desapareceu. Tudo estava a serviço de todos os homens ("comunismo original"). Deus havia concedido aos primeiros pais o poder de usar (potestas utendi). Depois do pecado e antes que se desse o fenômeno da terra na propriedade de pessoas ou grupos individuais aparece a "potestas", o direito de dividir e apropriar-se da terra. Em um terceiro momento, uma vez parcelada a terra, aparece a propriedade no sentido estrito", DAMIATA, M., OCKHAM, G., "Povertà e potere", SF, 75,1-4(1978), 305-310.

14 "Em primeiro lugar, pois, provo pela Sagrada Escritura e por outros textos não desprezíveis, que existiu, fora do povo de Deus e fora da Igreja Católica, verdadeiro domínio das coisas temporais e verdadeira jurisdição temporal, não apenas permitida, mas também concedida e ordenada por Deus... Por essas palavras fica mais que evidente que o Senhor deu a alguns infiéis coisas temporais e que, portanto, os infiéis tiveram verdadeiro domínio dessas coisas", OCKHAM, Op. cit., 98-99.
} 


\section{Uso e propriedade}

Não se é proprietário pelo simples fato de usar uma coisa qualquer, senão pela intenção apropriativa. O homem que renuncia à pretensão de possuir o que pertence somente a Deus, se converte em Senhor de todas as coisas, em dono do universo. Este é o grande tesouro da pobreza, tal como viveram Cristo e os apóstolos.

Essa teoria será logo objeto de apaixonadas discussões pelas implicações que tem na vida concreta, no uso quotidiano que os franciscanos fazem das coisas desse mundo, das dizem que não são proprietários, e diante das quais afirmam ser soberanamente livres.

Para a facção dos espirituais, o "uso pobre" será o complemento indispensável da teoria da desapropriação espiritual e jurídica. Para outros, esse aspecto é secundário e, mantendo a liberdade diante das coisas usadas, o uso requerido seria o moderado, comum a todos os cristãos.

Essa é outra linha que se pode lançar para o futuro desde a discussão franciscana do século XIV: o uso pobre, seja qual for o nível de austeridade e radicalidade que suponha, é um dos pontos discutidos, porém, sem dúvida, um dos elementos com mais vigência em nosso presente, implica uma reestruturação global da relação do homem com as coisas.

Outro dos vieses projetados para a modernidade é a distinção entre ter e dominar: o ter franciscano se reduz à utilização dos bens da criação em total respeito à natureza mesma das coisas, tal como têm sido criadas por Deus, para suprir as necessidades básicas implícitas no direito natural da vida.

A tese franciscana contradiz o ter apropriativo oposto à vontade do Criador, porém não configura somente uma proposta ascético-mística de perfeição individual: põe na tela do juízo a realidade eclesiástica e social contemporânea.

$O$ direito ao uso é a resposta natural às exigências naturais e primárias de subsistência. O "actus utendi" não é a expressão de liberdade, mas de necessidade. O "usus facti" é o contrário do "dominium", que implica reclamar e reconhecer socialmente o "jus utendi", ao qual os franciscanos, seja qual for sua tendência espiritual, renunciam.

Não estamos somente diante de querelas internas acerca do uso mais ou menos pobre das coisas. O que está em jogo é o direito natural à subsistência que o sistema de apropriação dominante na sociedade torna inviável para grandes setores da sociedade. 


\section{Chave de leitura e lugar social}

As coisas são vistas em conformidade com o tipo óculos e de lentes que cada qual carrega ${ }^{15}$ e através dos quais, sentado à janela, contempla o mundo. Os estudiosos contemporâneos sublinham a dificuldade de ter que passar, obrigatoriamente, através de uma leitura dos acontecimentos feita pela classe social dominante. Lê, interpreta e escreve a história aquele que se apropria da cultura, do dinheiro e do poder. A história que temos em mãos foi, habitualmente, escrita pelos vencedores.

"Entre todas as questões levantadas ao historiador por um testemunho do passado, das mais importantes, é a situação social do testemunho. Com muito mais razão, quando o documento trata um assunto como o da pobreza: acaso não é geralmente o rico aquele que escreve a esse respeito?

"Os tratados medievais abundam sobre o problema da pobreza. São obras de clérigos. Porém os clérigos não constituíam uma classe socialmente homogênea: diante de um desses tratados é importante conhecer o lugar de seu autor na Igreja e na sociedade; diante de escritos de clérigos de formação e origem diferentes, trata-se de avaliar com precisão as incidências de sua situação na sociedade sobre suas preocupações intelectuais e suas relações sociais" ${ }^{\prime 16}$.

São Tomás, ao falar da propriedade, se mantém dentro da doutrina tradicional da Igreja. Juntamente com toda a patrística, sustenta que, no estado de justiça original, os bens desse mundo eram "comuns e indivisos". Tudo pertencia a todos, não havia propriedades privadas, não se tinha ainda feito a divisão dos bens, nem levantado muros e cercas que distinguissem o patri-

\footnotetext{
15 "Num primeiro momento devemos distinguir um duplo lugar produtivo do discurso teológico: 'lugar social' e 'lugar epistêmico'. Essa distinção, por sua vez, está ligada à compreensão de um duplo regime que afeta as regras do pensar. A reflexão teológica tem um certo grau de autonomia, ao ser governada por si mesma, por leis próprias e exclusivas. Há uma normatividade teórica à qual a teologia se submete, vinda de sua própria constituição e de seu modo próprio de funcionamento. A teologia tem Regras próprias, que dependem da natureza de seu discurso e não são comandadas por interesses externos à teologia. É o campo fundamentalmente da sintática e inclusive da semântica teológica. A teologia tem um estatuto teórico próprio, original, único e autônomo. Tal regime de autonomia define o lugar de produção dos conhecimentos: o 'lugar epistêmico'. É o lugar das regras internas do pensar teológico", LIBÂNIO, J.B., Teologia da Libertação, Roteiro didático para um estudo, São Paulo, Loyola, $1987,123$.

${ }^{16}$ SCHMITT, J-C., "Les citations bibliques et canoniques dans les traités médiévaux sur la pauvreté" (XIV-XV siécles), in MOLLAT, M., (org.) Études sur l'histoire de la pauvreté, Paris, 1974, 547.
} 
mônio comum da humanidade. A propriedade privada foi introduzida pelo direito positivo humano "perfecit legem naturae". Analogamente, a roupagem e a servidão são aperfeiçoamentos adquiridos ao longo da história. Para Tomás, a utopia, o mundo ideal futuro, terá superado a trilogia - nudez, liberdade e comunismo - das origens.

$\mathrm{O}$ gênero humano, como tal, não é capaz de liberdade e, portanto, o sistema feudal concede e protege aquela liberdade que é possível ter aos mais fracos, assim como assegura o alimento aos menos capazes. A roupagem embeleza os corpos, adornando a sociedade com a admirável distinção de estados, de classes, sacramento na terra da admirável ordem divina. Olhando o bem comum, a ordem positiva humana estabelece a propriedade privada como o sistema mais conveniente. No entanto, o uso dos bens pertence a todos, tanto que, no caso de necessidade, todas as coisas voltam a ser comuns $^{17}$

Os autores franciscanos do século XIV não diferem muito de São Tomás, quanto ao modo de conceber o estado original do ser humano. Porém, para o autor do Sacro Commercium e seu contexto da Ordem Franciscana, o paraíso tem que ser reconquistado. Vestuário, escravidão, propriedade privada não são aperfeiçoamento do ser humano. $\mathrm{O}$ homem "nu" segue sendo o ideal futuro, assim com a perfeição de sociedade terá que ser buscada na perfeita liberdade e na ausência de apropriações.

O paraíso, que em todas as religiões e em todos os mitos desempenha o papel da utopia, é descrito como um jardim de delícias, porque ao não existir a propriedade, tudo pertencia a Deus ${ }^{18}$. Traje e propriedade indicam o estado de pecado e se contrapõem ao estado de inocência.

\footnotetext{
17 "De duas maneiras se diz que algo é de direito natural. A primeira, enquanto a natureza induz ao contrário. Assim poderíamos dizer que é do direito natural que o homem está despido, dado que a natureza não lhe deu vestimenta e visto que estes são frutos da arte. Do mesmo modo se afirma que a propriedade comum e a igualitária liberdade para todos são de direito natural. A diversidade de propriedades privadas e a escravidão não provêm da natureza, mas da razão humana para utilidade da vida humana. Nesse sentido afirmamos que a lei natural não tem sido modificada, mas aperfeiçoada”, TOMAS, Summa Th., 1a, 11ae; q 94, ad 3 um. Contra a doutrina de S. Tomás argumenta Olivi em seu tratado sobre o usus pauper.

18 "A idéia tinha sido expressada de modo totalmente coincidente por São Boaventura: 'A pobreza mais evangélica consiste em renunciar a todas as coisas, tanto em particular como em comum. O homem nasce despido e, se não houvesse o pecado, aquela nudez teria sido conservada, não apropriando-se o homem de coisa alguma. Quem quer redimir-se do pecado deve acomodar-se àquela pobreza primitiva', De perfectione evangélica, q.2, a.1, - Opera Omnia, Quaracchi, V, 129, O cardeal franciscano Bertrand de la Torre, respondendo à pergunta do Papa, conclui sua contribuição dizendo que - não é conveniente dizer que Cristo e os apóstolos tiveram acesso ao uso de determinada série de coisas, cuja propriedade permanecia sendo só de Deus. Suas vidas valorizaram, enquanto possível, o estado de inocência e o direito natural no qual todas as coisas eram comuns. Afirmar que algo é meu e algo é teu está permi-
} 
Recordemos que para São Tomás, assim como a graça aperfeiçoa a lei natural, de modo análogo o traje aperfeiçoa a nudez, a servidão feudal aperfeiçoa a liberdade e a propriedade privada leva à perfeição a liberdade comum. Para os dominicanos, a propriedade é uma perfeição e, portanto, Cristo e os Apóstolos não puderam carecer de uma das possíveis perfeições da natureza.

\begin{abstract}
Para Duns Scotus, ao contrário, a propriedade privada aparece "racionalmente depois do pecado, porque a posse comum de todos os bens se teria convertido, então, contrária à convivência pacífica, visto que o malvado e o ambicioso se apoderariam para além dos limites do necessário, inclusive, exercendo violência sobre aqueles que quisessem usar os mesmos bens para suprir suas necessidades. A propriedade comum se voltaria contra o sustento necessário quando os mais fortes privam os demais do indispensável. Considerando, pois, o estado em que o filósofo encontra os homens, a política de Aristóteles, em vista de que nem todas as coisas sejam comuns, resulta muito melhor que a de Sócrates, que queria retornar à propriedade comum" 19 .
\end{abstract}

Para os franciscanos a propriedade está na esfera do pecado e da morte e, de algum modo, fruto do pecado. Portanto, de modo análogo como é necessário lutar contra o pecado para construir o mundo, segundo Deus, assim também teria que lutar contra a propriedade. Se o mundo desejado por Deus, o mundo escatológico elimina a propriedade, conseqüentemente os "perfeitos", tais como Cristo e os apóstolos, os religiosos não podem ter propriedades.

O Capítulo Geral de Perugia, em 1322, em uma carta circular aos cristãos, afirma que Cristo propõe aos homens o caminho da perfeição; conseqüentemente os apóstolos caminham eles mesmos em tal via de perfeição; de modo que, deixam seu exemplo como herança para que outros também possam viver em perfeição. Portanto, não possuíram coisa alguma, nem por direito de propriedade ou senhorio, nem em razão de nenhum outro tipo de direito próprio ou especial.

tido pelo direito civil e pelos costumes humanos, contrários à equidade natural. Tudo o que existe é somente propriedade e domínio de Deus", TOCCO, F., La questione della porvertà nel Secolo XIV, Napoli, 74.

${ }^{19}$ SCOTUS, Duns, Op. cit., IV, d.15,q2, concl. 2: Vivés, XVIII, 258ab. 


\section{Direito de propriedade}

João $\mathrm{XXII}^{20}$ põe na boca dos franciscanos duas afirmações: Uma, que "Nosso Redentor e Senhor Jesus Cristo e os Apóstolos não tiveram nada em particular, nem sequer em comum". Outra, "que Nosso Redentor e seus Apóstolos não tinham em modo algum direito a usar daquelas coisas que a Escritura testemunha que possuíam e, tão pouco, tinham direito de vendêlas ou dá-las, nem a adquirir outras com elas.

Estão em discussão dois grandes temas: $\mathrm{O}$ primeiro é o direito à propriedade privada, tanto pessoal como comunitária. O segundo é o direito mesmo à propriedade, seja pessoal como comunitária.

Se os franciscanos negam a Cristo e aos apóstolos tal direito de propriedade é porque tanto menos é devido ao homem. O homem "perfeito", o homem verdadeiro, o homem escatológico, se vê desenhado no mundo franciscano como um ser capaz de convivialidade com todas as coisas: irmão, nunca amo, co-participe da filiação divina, nunca dono de seus semelhantes.

A proposta franciscana considera que a propriedade como tal é sacrílega, porque usurpa os direitos de Deus, e isso para João XXII destrói pela base a catolicidade da fé: aceitar, em conformidade com a fé, a tese minorítica, suporia que somente eles estão com a verdade e todo o resto dos cristãos, que admitem a propriedade como legítima estaria no erro.

$\mathrm{Na}$ realidade, o perigoso, o "herético" da utopia franciscana é que se apresenta como postura teórico-prática diante da realidade. Como uma tomada de posição e uma declaração de princípios operacionais, a perspectiva franciscana propõe a criação de um sistema orgânico e complexo de relações religiosas, sociais, econômicas, políticas e culturais.

Olivi anuncia que haverá um papa (o "anti-cristo místico" joaquinita) que se converteria em cabeça de uma Igreja mundana, ligada aos poderosos da terra, ávida por riqueza, ambiciosa por poder e, portanto, hostil à verdadeira Igreja, a dos pobres, a dos humildes e dos desprezados, até o ponto de persegui-los, fazê-los sofrer, inclusive fazê-los crer que estavam no erro, como se Cristo fosse o Cristo dos poderosos e não dos pobres e aflitos. Para Olivi existe uma consonância total entre o sofrimento de Cristo e de todos os que, come ele, são pobres, aflitos e sofredores ${ }^{21}$.

\footnotetext{
${ }^{20} 13$ de Novembro de 1323, Bula "Cum inter nonnullos".

${ }^{21}$ MANSELLI, R., "Pietro di Giovanni Olivi spirituale, Chi erano gli spirituali," Atti del III Convegno Internazionale di studi Francescani, Società internazionale de studi Francescani, Assisi, 1976, 181-204, p. 192.
} 


\section{Os pobres e a Igreja dos pobres}

O movimento franciscano atual tem que ser consciente das dificuldades inerentes a toda atualização histórica das grandes instituições do passado. É preciso iniciar reconhecendo a diferença dos pressupostos teológicos atuais. As propostas dos frades do século XIII-XIV, em alguns aspectos dificilmente podem ser vinculadas com os interesses e utopias do século XXXXI. De qualquer modo, também há que reconhecer que muitas temáticas e outros tratamentos de problemas são percebidos como imediatamente próximos, repicando com força em nossa mesma longitude de onda.

Uma conclusão que vem das profundezas da primeira metade do século XIV e que me parece ter um enorme alcance para o futuro: Os franciscanos teriam que trabalhar na construção de um mundo pobre e fraterno, nunca rico e opulento. A utopia franciscana segue vigente. Ligada à sua tradição histórica, propõe um sistema relacional totalmente novo e original.

\section{Outro mundo é possível}

Inegável é que foi o Senhor quem conduziu Francisco. Que ninguém lhe revelou o que tinha que fazer uma vez que o Senhor mesmo lhe presenteou irmãos. Ninguém, fora do mesmo Senhor, de quem nada pode sequer fazer menção, fora do único altíssimo Senhor. Nessa condução divina há um fato que marca o "antes" e o "depois". Desde então, tudo foi distinto, nada foi igual. Um leproso, que se queira ver como imagem antitética do Cristo glorioso do sistema vigente, constitui o umbral entre dois mundos onde o doce e o amargo se tocam.

Pretender uma descrição da opção de Francisco de Assis que divida o religioso do sociológico seria falsear de "início ao fim" a perspectiva da época. Francisco foi amadurecendo lentamente sua opção no âmbito sociológico-político-religioso-cultural, unida em uma só e indivisível realidade medieval. É o mundo do comércio, do dinheiro, da vida fácil, da diferença brutal de classes sociais, de contato diário e direto com a fome, a miséria, o sofrimento. São os sonhos de nobreza e cavalheiresca fidalguia, a realidade nua da guerra em nome de não se sabe nunca que deus, que amo e nem mesmo que povo. É o asco progressivo que se vai convertendo em um grande fastio, vazio de sentido e ausência de projeto ${ }^{22}$.

Ser "menor" supõe ter adquirido um habitat próprio, peculiar. Lugar debaixo do sol onde alguém se sinta como peixe na água: o menor está ale-

\footnotetext{
${ }^{22}$ BÓRMIDA, J., "Minoridad y solidariedad en y desde América Latina. Una opción desde lo sociológico, Cuadernos Franciscanos, 63, marzo 1983.
} 
gre na convivência com pessoas vis e desprezadas, com pobres e fracos, enfermos e leprosos, com os mendigos do caminho (1R 15).

De fato, só desde o abandono ideológico (ingênuo?) dessa perspectiva sociológica, é possível armar um imponente edifício hermenêutico para interpretar a Regra. Se todos sabem bem como governam os príncipes desse mundo, o que significa em concreto a vassalagem, o poder e o mando dos chefes da sociedade; se todos sabem bem, pela ciência e experiência, o conteúdo da opressão dos poderosos..., então é fácil, muito fácil, entender qual é o alcance da afirmação, mandato, exortação de ser os irmãos, exatamente ao contrário (1R 5).

Os irmãos sabiam (e sabemos) muito bem onde vivem, como vestem e quanto gastam os ricos desse mundo. Muito simples ainda para o entendimento de analfabetos do tempo: os irmãos não vivem em palácios, não têm contatos habituais com a nobreza, a própria vestimenta os identifica com uma determinada classe social (1R 2).

A forma de vida proposta pelo Senhor a Francisco de Assis e seus seguidores voluntários, também guiados pela inspiração divina (1R 2), é convite a tomar posição entre as classes sociais desse mundo presente. O "sair do século" significa pura e simplesmente que a sociedade da época não pode ser reformada. Tem que ser refeita desde os alicerces. E só se pode colocar como fundamento o que está mais em baixo: os abandonados, os pobres, os fracos, os leprosos, para tanto, é mister voltar a escolher a pedra angular que fora rejeitada pelos arquitetos falidos da atual sociedade.

Essa opção, no campo sociológico, teria que ter significado no caso de Francisco e dos seus, um sair da Igreja. Nem o magistério oficial e solene da época conseguia estabelecer uma divisão, ainda que não fosse mais que teórica entre Igreja e Sociedade.

A pobreza não está entre sóis simbólicos do franciscanismo. Sim, e certamente, os pobres. Cristo pobre, sua Mãe pobre e os pobres desse mundo. A Pobreza será "Dama Pobreza", Igreja concreta que ele vai formando ao seu redor, nunca abstração, mas realidade sonhada e, progressivamente, vivida. Conhecida pelos mendigos dos caminhos e descoberta pelo grupo de Francisco.

No entanto, mais ainda que a pobreza real e encarnada nos pobres concretos (Jesus, Maria, mendigos e leprosos), temos que recorrer a outra palavra-chave traduzida em leis, atitudes, forma de vida: a não-propriedade ou não-apropriação. Basta ler o prólogo e o primeiro capítulo da Regra não Bulada para entender que a não-propriedade é o conceito chave que permite entender tudo o que segue na forma de vida de Francisco e seus irmãos. 
Nada temos como propriedade privada senão nossos próprios vícios e pecados. Todos os bens e benefícios gratuitamente são concedidos por Deus que nos ama como miseráveis, blasfemos, podres, hediondos, ingratos e maus. Na verdade, a única coisa que temos como propriedade oferecida é o próprio Deus, todo o bem, sumo bem, bem total e que é só bom. Fora de Deus pouco faz falta, uma vez tendo o que vestir e comer, já são suficientes. $\mathrm{O}$ resto, toda a honra, toda a glória, toda a bênção e todos os bens... devemos restituí-los ao doador de todos os bens. Só assim possuiremos o único bem que importa e que só basta para tudo. Nenhuma outra coisa é necessária de todo o que há no mundo, além do comer e vestir. Não há que levar nada pelo caminho, só aceitar moradas e Igrejas pobrezinhas que de nenhum modo e sob nenhum pretexto podem ser apropriadas: nem lugar, nem nada, nem ninguém nesse mundo. $\mathrm{O}$ irmão tão pouco pode apossar-se de algum cargo, ministério ou serviço. Por que se nada possui, não tem que lutar por nada, de nada tem que defender-se: nem privilégios vetados a outros, nem lugares proibidos, nem sequer possuímos a verdade.

Esta não-apropriação é a condição que possibilita o mandamento da Regra: não armar conflitos, nem contendas, mas ser mansos, pacíficos, humildes... em todo o lugar desejar e transmitir a paz. Não tendo nem terras, nem interesses econômicos na Europa, pode não guerrear com o muçulmano. Sua radical desapropriação pode torná-los amigos e companheiros dos hereges e percorrer um caminho conjunto. E se sobra alguma dúvida ainda em conseqüência da absoluta desapropriação, encontra-se a carta de um dos ministros da Ordem, o ápice dos ensinamentos sobre a negação à propriedade: Contentando-se com aquilo que o Senhor lhe dá, na medida do irmão concreto, sem exigir sequer que o outro seja cristão e sem poder de impor outra penitência que ele "vete e não peque mais", e com a indicação de que o ministro, por sua parte, está disposto a trabalhar desse modo para que os demais o imitem.

Pareceria que toda a renúncia de toda a propriedade, de qualquer índole ou natureza que for, com a única exceção dos próprios vícios e pecados, é a condição indispensável para entender o Evangelho de Francisco de Assis. Por que os próprios pecados são pouca coisa diante da misericórdia de Deus, mesmo que possam produzir amargura ao irmão superior ou tristeza no pecador.

Nesse contexto de insurreições e revoltas civis, o nome de menores não significa primariamente os excluídos, os debaixo, os humildes e humilhados, mas aqueles que lutam por uma sociedade nova. Os Menres são a classe emergente, o novo sistema alternativo ao feudal. Ao chamar-se meno- 
res, o grupo passa a optar por um partido político e por uma utopia política de Assis.

$\mathrm{Na}$ chave econômica poderíamos dizer que a minoridade significaria: outra economia é possível. Há alternativas possíveis para a nossa sociedade, para nossas formas de governo e participação na cidadania. Outro mundo é possível.

Uma crônica escrita por volta de 1210 nos diz que o grupo primitivo franciscano se autodenominou como pobres e menores. O movimento aposta na causa dos pobres menores se identifica com os pobres da sociedade emergente, são os pobres da nova sociedade. Seu projeto proclamava que era possível uma verdadeira alternativa social só a partir dos pobres, como pobres. Desde os pobres é possível outra economia. ${ }^{23}$

\section{Uma nova ordem econômica, um novo sistema de propriedade}

Quando o papa publica a condenação de heresia ao movimento franciscano, põe na boca dos irmãos a afirmação de que Cristo e os apóstolos não tinham o direito de possuir, ou pior, não tinham nem sequer o direito de usar ou alienar as coisas que usavam.

Cristo é o novo Adão, é o homem perfeito, o protótipo pensado por Deus como a grande utopia do homem, na qual ensinou a viver a seus discípulos. Nessa ótica, o homem como tal, o homem perfeito segundo Deus, que soube reconhecer o plano que Deus tem designado na terra e na história, esse homem não tem o direito de possuir. O homem se define como filho-irmão, não como pai-dono, tanto dos outros homens como das coisas. Essa perspectiva (chave, horizonte, lugar hermenêutico) se une, clarissimamente, à fonte mais cristalina do pensamento de Francisco de Assis.

A mensagem que os franciscanos teriam que dar aos políticos que trabalham por instaurar uma nova ordem mundial, a dos economistas que querem imaginar uma nova ordem econômica humana, a dos ambientalistas que apostam em melhorar a qualidade de vida do ser humano, a dos preservacinaistas que brigam por conservar as espécies em extinção, especialmente a do ser humano, a dos pastoralistas que querem construir uma Igreja mais evangélica... a todos eles, o anúncio basilar, primevo, fundante é esse: começar por revisar a fundo a teoria e o exercício da propriedade e do poder. Não se trata de ressuscitar propostas mais ou menos fracassadas ao longo da história, inclusive recente, tais como abandonar a propriedade privada para apoderar-se coletivamente dos bens da terra. Trata-se de colocar no quadro

${ }^{23}$ Cf. BÓRMIDA, J., "O nome de menores: o Sitz im Leben primitivo", Cadernos da ESTEF, 18, 1997/1, 74-85. 
do julgamento a vontade dominadora do ser humano, seja como pessoa, seja como coletividade.

O homem não tem o direito a possuir, a vender, a comprar, a usar, como se as coisas fossem realmente dele ${ }^{24}$. $\mathrm{O}$ caminho de salvação para o mundo do homem começa quando este deixa de ver o mundo como propriedade privada, como área de caça da qual é o dono, senhor, proprietário e com ele faz o que lhe apraz. Se quer preservar a vida no planeta, reforme-se o sistema de propriedade. A revelação divina dada no Verbo feito homem-pobre, sem propriedades, sem domínio, anunciador do ser humano perfeito no mundo acabado, indica um caminho translúcido para o homem do futuro.

Francisco de Assis foi declarado patrono dos ecologistas e, não entenderemos a proposta ecológica de Francisco de Assis se não examinarmos seriamente as conseqüências para o presente de sua renúncia radical a toda a propriedade privada e comunitária das coisas criadas, animadas e inanimadas, homens e animais, fiéis e infiéis.

A democracia e a liberdade estão na moda. Se Guilherme de Ockham ensinasse, hoje, uma disciplina em uma Universidade possivelmente seria escutada com interesse, ainda que não com muito assombro. Muitos dos elementos que aparentemente se perderam na batalha contra o sistema dominante na primeira metade do século XIV, através dos séculos forma recobrando sua validade. Contudo, creio que, desde a problemática que temos considerado, existem alguns elementos de grande interesse e novidade na possível Boa Nova que os franciscanos podem dar para o mundo do futuro.

Dissemos várias vezes que o tema da propriedade e do poder são inspiráveis. Quando lemos mensagens franciscanas promulgadas para o mundo atual, torna-se fácil encontrar temas tais como Liberdade, Espírito, Respeito à pessoa, Fraternidade, etc., todos perfeitamente legítimos. Contudo, se compreendemos a intuição mais profunda da utopia franciscana contida no "Cristo sem propriedades", o núcleo de uma mensagem franciscana, as democracias, as emergentes e caducas, devem ser um grito de alerta sobre o sistema vigente de propriedade. Não se pode falar de liberdade, de participação, de co-gestão..., de verdadeira democracia, quando a "posse dos bens"

\footnotetext{
24 "No plano da Criação, os bens da terra são destinados à subsistência digna de todos os homens" Paulo VI, Populorum Progressio, 23. "A diferença consiste no modo de entender o direito de propriedade. A tradição cristã não tem sustentado jamais esse direito como absoluto e intocável. Ao contrário, sempre o tem entendido no contexto mais amplo do direito comum de todos usar dos bens da inteira criação: o direito à propriedade privada como subordinado ao direito, ao uso comum, ao destino universal dos bens" (João Paulo II, Laborem excercens, 14). Se quer ampliar esse tema, cf. ANTONSCICH, R., SANS, J.M., Ensino social da Igreja, Petrópolis, Vozes, 1987; ANTONSICH, R., MUNARRIZ, J. M., Doctrina social de la Iglesia, Madrid, 1987; IRIARTE, G., La enseñanza social del evangelio, Bogotá, 1985.
} 
culturais, materiais, espirituais e, quando todo o poder de decisão está nas mãos de poucos.

Tem-se a impressão de que muitos povos sacudiram o peso da opressão "coletivista", buscando mais os bens e as propriedades do que a liberdade. Ter-se-á que ver como se desenrola a história nos próximos anos, porém não parece que o milagre seja produzido. A mensagem franciscana aos povos que buscam a liberdade pode, hoje, retornar à insistência nos tópicos tradicionais em consonância com sua mais pura tradição. O franciscano, quando fala de liberdade, de fraternidade, o governo popular, contemporaneamente, põe em relação os temas da pobreza, poder, propriedade, desapropriação, participação.

\section{Os pobres, "nova" chave hermenêutica}

Junto à propriedade e o poder, os franciscanos de hoje teriam que resgatar a tradição mais primitiva, das origens do movimento franciscano. Com Francisco de Assis é mister deixar que os pobres façam livremente sua irrupção na Ordem e na Igreja. É imprescindível construir uma sociedade nova, com novo sistema de propriedade e novo exercício do poder, porém, a partir dos pobres, com a ótica dos pobres reais.

Nesse campo poderia ser precioso atualizar, mas além e esquecendo-se da casuística medieval, o tema do uso pobre, dos meios pobres, da austeridade, muito discutidos na época que estamos estudando e que voltam a ter enorme atualidade em toda a área da ecologia e preservação do meio ambiente. Especialmente quando nos dirigimos aos países pobres e aos pobres desses países: somente os meios pobres e a não imposição de modelos da sociedade opulenta pode salvar o mundo, ao mundo pobre e ao mundo rico. $\mathrm{O}$ franciscano deve sentir-se cômodo, naturalmente, nessa visão das coisas. No entanto, para torná-la realidade, é mister superar seu "orgulho de ser um pobre especial" e deixar que os pobres reais invadam suas fraternidades e sua teologia. Esse texto me serve de conclusão.

A teologia da libertação nasce de outras opções fundamentais. Antes de tudo, parte da opção pela libertação dos pobres... Portanto, não se entende sem a irrupção dos pobres no cenário da sociedade e da Igreja. A Igreja dos pobres sublinha também a dimensão cristológica da experiência de Deus. Jesus se converte na medida e no modelo estrutural da nossa experiência de Deus. Ele se faz pobre. Convive com os pobres. Privilegia os pobres. Come com os pobres e torna-os destinatários primordiais e principais da Boa Nova (Lc 7,22; Mt 11,5). Ele nos revelou, pois, de onde e como experienciar Deus, seu Pai, na concretude da experiência com os pobres. 
Sem dúvida, a experiência de Deus no abaixamento, no aniquilamento, na kênosis foi um dos elementos mais originais da experiência de Jesus. A associação espontânea entre Deus e o Poder, entre Deus, a Glória e o Esplendor, nunca nos permitiria descobrir a Deus na fragilidade, no pequeno, no último do mundo. A vida de Jesus, na síntese do hino paulino, foi uma kênosis (Fl 2,5-11). Nada melhor que o pobre no nosso Continente representa esse último, esse kenótico. Experienciar Deus nele é imitar a Jesus na sua experiência de Deus. Por isso, a Igreja dos pobres oferece um contexto histórico para recriar a experiência de Deus originária de Jesus ${ }^{25}$.

Eu chamaria os irmãos da América Latina a fazer menos coisas pelo povo, no lugar do povo, para caminhar mais com o povo, trabalhando pela libertação com os meios do povo, com seus passos e ritmo do povo, assumindo as aspirações do povo.

Exigiria mais esforço em sintonizar a "rádio popular" do que em criar rádios a favor do povo, com programas feitos por gente que não é do povo. Aos estrangeiros é mister acreditar nos nativos, deixar-lhes lugar, abrir-lhes possibilidades e deixar que tenham o tempo para equivocar-se e ser eles mesmos. Que a Ordem Franciscana seja lugar onde o pobre tenha vez, tenha voz e tenha palavra. Não caiamos na excessiva tentação de ser a voz dos que não têm voz, e terminamos por não escutar a voz dos pobres. O problema é escutar e fazer ouvir a voz dos pobres.

\section{Résumée}

La non-propriété, comme une posture franciscaine, en son origine, est plus radicale que la pauvreté. En toute la pensée franciscaine il y a une personnification de la Dame Pauvreté, mais l'option pour la non-propriété est une attitude révolutionnaire et contestable devant l'attache aux propriétés et de l'usage des forces armées pour protéger les propriétés de l'Église.

Le franciscanisme veut vivre de la Providence comme forme de détachement radicale des biens matériels a fin de montrer plus de courage dans l'option pour le Règne de Dieu.

\section{Jerónimo Bórmida}

Doutor em Teologia pela Pontifícia Universidade Antonianum, Roma

Professor da Faculdade de Teologia do Uruguai lbormida@adinet.com.uy; jbormida@gmail.com

${ }^{25}$ LIBÂNIO, J. B., Op. Cit., 112. 